INVESTIGACIONES

de HISTORIA ECONÓMICA

IHE. Otoño 2009. Pp. 137-170

\title{
Actividades y estrategias económicas de la burguesía alicantina en los años cuarenta del siglo XIX
}

\section{Activities and economic strategies of the bourgeoisie of Alicante in the for- ties of Nineteenth Century}

\author{
PEDRO DÍAZ MARÍN \\ Universidad de Alicante
}

\begin{abstract}
RESUMEN
En este texto se analizan las principales actividades económicas que se desarrollaron en la ciudad de Alicante a mediados del siglo XIX impulsadas por unas dinámicas élites de nobles y burgueses. Se trataba de una economía modestamente diversificada, en la que el peso fundamental recaía en el comercio y la agricultura comercial. A continuación se examinan las estrategias económicas de estas élites que perseguían la creación de un estado de opinión con la intención de influir en los poderes públicos para que pusieran en práctica políticas económicas de fomento de la agricultura y de liberalización del comercio exterior.

PALABRAS CLAVE: Burguesía, Alicante, Estrategias Económicas, Agrarismo, Librecambismo Códigos JEL: N53, N73, N93

ABSTRACT

In this text we analyze the main economic activities that were developed in the city of Alicante in the mid $19^{\text {th }}$ century promoted by dynamic elite of aristocrats and middle classes. The economy was moderately diversified, the main weight falling on trade and commercial farming. Following this we examine the economic strategies of these elites who pursued the creating of a state of opinion in order to influence the authorities to put into practice economic development policies for agriculture and free trade.

KEY WORDS: Middle classes, Alicante, Economic Strategies, Agrarianism, Free trade

JEL Codes: N53, N73, N93
\end{abstract}




\section{Introducción ${ }^{1}$}

$\mathrm{E}$ ste texto analiza las principales actividades económicas de la burguesía alicantina en la década de 1840 y sus propuestas de crecimiento económico en un período en que se sucedieron dos modelos políticos distintos -el progresista y el moderado- y en el que se planteó abiertamente la polémica entre proteccionismo y librecambismo. El tema suscitó un gran interés entre los comerciantes y propietarios alicantinos que quisieron hacer oír su voz en los momentos en que desde Madrid se iban a tomar decisiones relativas a la liberalización del comercio exterior que afectarían directamente a sus intereses. El artículo pretende también indagar por qué una burguesía exportadora como la alicantina renunció a un librecambismo radical y optó por otro más matizado, tendencia que también se observa en otras burguesías. Ello exige tener en cuenta no sólo su discurso teórico expuesto en distintos medios, sino también el conjunto de sus intereses, vinculados al comercio de exportación, pero también a unas redes mercantiles en el ámbito nacional.

El trabajo se articula en tres partes. En la primera (epígrafe 2) se analiza, a través de fuentes fiscales principalmente, la composición de la burguesía en la que destaca con nitidez el grupo de los comerciantes, que ocuparon las principales instituciones económicas - Junta y Tribunal de Comercio-, políticas y administrativas - Ayuntamiento y Diputación-. Se trataba de un grupo bastante cohesionado, pese a las posibles diferencias políticas e ideológicas, y la presencia de nobles en él no empañó su carácter burgués. Eran los comerciantes y propietarios de tierras que habían sabido sacar provecho de las oportunidades ofrecidas por el liberalismo censitario.

En la segunda parte (epígrafe 3) se da un repaso a las principales actividades económicas de esta burguesía, en la que se observa una cierta presencia de comerciantes extranjeros, que contribuyeron a dar un carácter más abierto a la economía alicantina. Aunque era importante la agricultura comercial practicada en la Huerta - una llanura de regadío cercana a la ciudad-, y en otros lugares de la provincia, la principal actividad económica era el comercio. Hay que tener en cuenta que Alicante jugó un papel relevante como centro redistribuidor hacia el interior y otros puntos del litoral, como punto de salida a otros núcleos urbanos del Mediterráneo y como puerto exportador de productos agrarios. Esta inclinación agrarista y comercial se vio confirmada tras el fracasado intento de crear una industria metalúrgica a principios de los años cuarenta, que no resultó competitiva debido a los altos costes de producción, sobre todo del carbón.

[Fecha de recepción del original, 20 de junio de 2008 . Versión definitiva, 24 de febrero de 2009].

Deseo agradecer las sugerencias de los evaluadores de Investigaciones de Historia Económica, y de Salvador Calatayud y Jesús Millán; así como de mis compañeros de departamento Pablo Díaz, José Antonio Miranda y Miguel Ángel Sáez. 
El tercer apartado (epígrafe 4) consta de dos partes. En la primera se examinan las propuestas de la burguesía a través del semanario El Mensajero - publicado en 1846 y 1847- para impulsar el desarrollo agrario, eliminando los obstáculos que se oponían al crecimiento de una agricultura comercial y diversificada, no basada exclusivamente en el cereal. En la segunda parte se analizan las demandas de esta burguesía de una política comercial de signo librecambista, aunque -como se ha señalado- su inicial radicalismo se fue deslizando hacia un proteccionismo matizado. Este discurso lo desarrolló en forma de polémica con los principales defensores del prohibicionismo - los industriales algodoneros catalanes-, apoyando una reforma de los aranceles y la firma de un tratado comercial con Gran Bretaña, que permitiera la entrada de tejidos de algodón ingleses a cambio de que los británicos rebajaran los productos agrarios de la región, como la pasa o la barrilla. Sin embargo, la burguesía alicantina, a diferencia de lo que sucedió con otras burguesías exportadoras, como la gaditana, no consiguió articular un grupo de presión eficiente. No obstante, ello no impidió que, independientemente de su adscripción ideológica y atentos a las diferentes coyunturas políticas, como fueron las de 1841-1842 (de dominio progresista) y las de 1846-1847 (de dominio moderado), los comerciantes lanzaran campañas de opinión a través de la prensa, de los representantes provinciales en el Parlamento o de exposiciones al poder ejecutivo, tratando de influir en los poderes públicos para que pusieran en marcha políticas comerciales de signo más librecambista, poniendo fin al prohibicionismo que en materia de algodones fomentaban los fabricantes catalanes, al que consideraban contrario a sus intereses exportadores.

\section{El peso de los comerciantes}

La estadística realizada en 1841 por Manuel Cortina, ministro de Gobernación, fijó el volumen de riqueza de la provincia de Alicante en 7.721 .273 reales, de los que el 63\% correspondía a riqueza territorial —rústica y urbana- y el resto lo aportaban la industria y el comercio. Los datos resultaban increíbles, como no podía ser menos, dado que fueron aportados por los propios contribuyentes sin ningún control ni supervisión por los funcionarios de Hacienda ${ }^{2}$. La matrícula catastral de 1842, corregida por Madoz, elevó la riqueza imponible a más de 100 millones, siendo la riqueza territorial abrumadoramente mayoritaria en las tres provincias del País Valencia$\mathrm{no}^{3}$. Por lo que respecta a la provincia de Alicante, las actividades industriales y

Madoz (1995), p. 112. Pro (1987), pp. 199-216.

Plaza (1992), pp. 273-297. 
comerciales se hallaban muy concentradas. Cuatro ciudades, que reunían el 23,34\% de los habitantes, acumulaban el 41,7\% de la riqueza por estos conceptos, aportando Alicante y Alcoy más de la cuarta parte. En la capital de la provincia las actividades industriales y comerciales suponían el 58\% de la riqueza, los inmuebles urbanos el $23 \%$, mientras que la riqueza territorial se quedaba en el 19\%.

Según un padrón de los establecimientos públicos realizado en 1842 había en la ciudad 9 puestos ambulantes, 43 negocios de poca consideración y 554 puestos fijos, 250 dedicados a tareas artesanales y 254 a actividades comerciales, de transporte o servicios ${ }^{4}$. Entre los más frecuentes de estos establecimientos, los que se encontraban repartidos por todo el casco urbano, predominaban los incluidos en el sector terciario: tabernas, abacerías, carreteros o tiendas de ultramarinos. Las fuentes fiscales inciden en el mismo sentido. De los 858 contribuyentes que en 1852 pagaban el subsidio industrial y comercial, 209 (el 24,4\%) ejercían actividades relacionadas con el sector secundario y pagaban el 12,1\% de la contribución, mientras que los 649 contribuyentes incluidos en el sector terciario, el 75,6\%, pagaban el 87,9\% de la cuota. Una distribución similar se observa en otras ciudades mercantiles como Santander ${ }^{5}$. Dentro del sector terciario el mayor peso lo tenían los comerciantes, que suponían el $62,9 \%$ de los contribuyentes por este sector y el 47,5\% del total de contribuyentes por subsidio, y los transportistas que representaban el 21\% y el 15,8\% de los contribuyentes por sector terciario y de todos los que pagaban el subsidio respectivamente. Entre comerciantes y transportistas aportaban el 88,7\% de la cuota que pagaba el sector terciario y el 77,9\% de la cuota total (Cuadro 1). Dentro del grupo de los comerciantes destacaban 66 (el 16,2\% del total de comerciantes, y el 7,4\% de todos los contribuyentes) que pagaban el 68,3\% de la cuota que aportaba este grupo, lo que suponía el 49,8\% de la cuota total (Cuadro 2). Se trataba de mayoristas, comisionistas y almacenistas que ejercían el crédito y eran propietarios de tierras. De los grandes comerciantes que pagaban más de 1.000 reales de contribución, 28 tributaban, además, 32.381 reales por territorial, lo que suponía el 12,1\% de la cuota total pagada por los vecinos y el 9,1\% de la pagada por el total de contribuyentes, vecinos y forasteros $^{6}$. Dentro de este selecto grupo se reclutaban los miembros del Ayuntamiento y los directivos de la Junta y del Tribunal de Comercio ${ }^{7}$.

$4 \quad$ Archivo Municipal de Alicante (AMA en adelante) Borrador General de los establecimientos públicos de la ciudad de Alicante, 1842. Arm. 3. Legajo 32. Olim Diversorum.

Hoyo (1993), p. 22.

Boletín Oficial de la Provincia (BOPA en adelante), 1852. Díaz (2000), pp. 309-338.

Díaz (1998a). 
CUADRO 1

CONTRIBUYENTES DEL SECTOR TERCIARIO EN 1852

\begin{tabular}{lccrr}
\hline Actividad & Contribuyentes & $\%$ & Cuota & $\%$ \\
\hline Comercio & 408 & 62,9 & $145.195,0$ & 83,1 \\
Transporte & 136 & 21,0 & $9.748,0$ & 5,6 \\
Prof Liberales & 82 & 12,6 & $15.025,0$ & 8,6 \\
Hostelería & 15 & 2,3 & $4.376,0$ & 2,5 \\
Otros & 8 & 1,2 & 440,0 & 0,3 \\
\hline Total & $\mathbf{6 4 9}$ & $\mathbf{1 0 0 , 0}$ & $\mathbf{1 7 1 . 7 8 4 , 0}$ & $\mathbf{1 0 0 , 0}$ \\
\hline
\end{tabular}

Fuente: BOPA, 1852

CUADRO 2

CONTRIBUYENTES COMERCIANTES EN 1852

\begin{tabular}{lcccr}
\hline Tramos & Contribuyentes & $\%$ & Cuota & $\%$ \\
\hline Más de 2000 & 19 & 4,7 & 47.600 & 32,8 \\
Más de 1000 & 23 & 5,6 & 35.255 & 24,3 \\
$\mathbf{5 0 0 - 1 0 0 0}$ & 24 & 5,9 & 16.205 & 11,2 \\
$\mathbf{1 0 0 - 5 0 0}$ & 128 & 31,4 & 32.518 & 22,4 \\
Menos de 100 & 214 & 52,5 & 13.617 & 9,4 \\
\hline Total & $\mathbf{4 0 8}$ & $\mathbf{1 0 0 , 0}$ & $\mathbf{1 4 5 . 1 9 5}$ & $\mathbf{1 0 0 , 0}$ \\
\hline
\end{tabular}

Fuente: BOPA, 1852

\section{Principales actividades económicas a mediados del siglo XIX}

\subsection{Una economía orientada desde el comercio: los intereses agrarios y comerciales de la burguesía}

El deseo de los comerciantes de forjarse un patrimonio agrario estaba en la base de su interés por la tierra, no sólo por lo que podía suponer de negocio, sino también porque su propiedad otorgaba prestigio y permitía el acceso a la categoría de ciudadanos con derechos políticos ${ }^{8}$. Ello ayuda a explicar la importante participación del 
capital mercantil en la compra de tierras desamortizadas en toda la provincia durante los años cuarenta ${ }^{9}$. Los comerciantes llegaron a controlar una buena parte de la tierra cultivable e impulsaron una agricultura comercial, complemento de la actividad mercantil. Aunque los progresos más notables de la agricultura valenciana se dieron en el decenio 1870-1880, ya antes había mostrado su capacidad para adaptarse a la demanda e introducir innovaciones, como la expansión del regadío, la especialización agraria o el cambio tecnológico ${ }^{10}$. Estimuladas por el fuerte incremento de las exportaciones de productos primarios y por la expansión urbana, las agriculturas del área mediterránea crecieron más entre 1840 y 1880 que antes de 1840, al contrario que las agriculturas del interior basadas en el cereal ${ }^{11}$. La agricultura alicantina, aunque de forma más modesta, participaba también de esta tendencia. Este tipo de agricultura intensiva, de rendimientos relativamente elevados, controlada por el capital urbano, se practicaba en la Huerta, una llanura de más de treinta mil tahúllas. Se trataba de una agricultura en la que el regadío tenía su importancia, desarrollada también en otros lugares del litoral valenciano, que proporcionaba cereales, hortalizas, frutas, vino, aceite, almendra, pasas, naranjas, limones, barrilla, esparto; productos entre los que predominaban los dedicados a la exportación, principalmente el vino, la barrilla o las pasas ${ }^{12}$.

Aunque los intereses agrarios de la burguesía alicantina eran importantes, su principal actividad económica era el comercio. Tras la crisis que para el sector exterior supuso la pérdida de las colonias americanas, a lo largo del primer tercio del siglo XIX tuvo lugar un proceso de recuperación basado en la reorientación de los flujos comerciales hacia Europa occidental y en una reestructuración de las exportaciones, entre las que predominaban con nitidez los productos primarios ${ }^{13}$. A lo largo del siglo XVIII se había ido conformando una tradición comercial que se consolidó durante la siguiente centuria, como atestiguaba Madoz al afirmar que el comercio era la principal actividad económica a la que se dedicaban los habitantes de la ciudad de Alicante, que redistribuía los productos que llegaban a su puerto hacia Madrid y otros puntos del país, para lo que contaba con más de un centenar de carruajes $^{14}$. También era el punto de salida de los cereales de La Mancha hacia mercados urbanos del Mediterráneo; y era especialmente importante el tráfico de cabo-

\footnotetext{
Sánchez Recio (1986).

Garrabou (1985a), pp. 331-344 y (1985b), Mateu y Calatayud (1996), pp. 101-124. Calatayud, Millán y Romeo (1992), pp. 125-138.

Llopis (2003), pp. 320-324.

Ruiz (1985), Millán (1981), Roca de Togores (1986 [1849]).

Prados (1984), pp. 137-138, (1988).

Giménez (1981), pp.377-399, Madoz (1995), Archivo Histórico Provincial de Alicante (AHPA), Hacienda. Libro 1232. Subsidio de la capital. 1844.
} 


\section{CUADRO 3}

DESTINO DE LAS EXPORTACIONES EN 1843

\begin{tabular}{lc}
\hline Puerto de destino & № de facturaciones \\
\hline Marsella & 119 \\
Orán & 43 \\
Belfast & 24 \\
Argel & 23 \\
Londres & 23 \\
Amsterdam & 14 \\
Génova & 7 \\
Rotterdam & 7 \\
Hamburgo & 6 \\
Gibraltar & 5 \\
San Juan de Luz & 2 \\
Londonderry & 2 \\
\hline
\end{tabular}

Fuente: AHPA. Hacienda. Libro 215

taje con Cataluña. En 1835 entraron en el puerto de Barcelona 131 barcos procedentes del puerto de Alicante, cifra sólo superada por Valencia con 272 embarcaciones $^{15}$. En 1846 desde Alicante se introdujeron en Cataluña cerca de 300.000 fanegas de trigo, lo que suponía el 49,3\% del total desembarcado por cabotaje en los puertos catalanes; el $40 \%$ de la cebada y cantidades más modestas de centeno, maíz y harina ${ }^{16}$.

Ocupaban un lugar preferente entre las exportaciones los productos agrarios, como el vino, la barrilla, el esparto, las pasas o el almendrón (almendra en pepita) en menor medida algunos productos mineros - plomo y plata- y productos cerámicos - ladrillos y losetas-, que eran enviados a Europa occidental y norte de África (Cuadro 3) ${ }^{17}$. En 1834 los productos agrarios exportados por los puertos del País Valenciano alcanzaron un valor superior a los 16 millones de reales, de los cuales el 49\% correspondió a los puertos de la provincia de Alicante, siendo el de la capital el más activo, pues exportaba el $25 \%$ del total del País Valenciano ${ }^{18}$. Las pasas y

\footnotetext{
$15 \quad$ Fradera (1987), p. 226.

16 Díaz (2003), pp. 31-62.

17 La importancia de Gran Bretaña como destino de las exportaciones alicantinas es más relevante de lo que refleja el cuadro, pues hay que tener en cuenta la pasa que salía del puerto de Denia hacia el mercado británico.

18 Piqueras (1985).
} 
la barrilla supusieron para el período 1834-1846 el 13\% del total de las exportaciones españolas a Gran Bretaña. Ahora bien, la evolución de ambos productos fue muy desigual. La barrilla, que en 1834 aportaba más del 11,5\% a las exportaciones a Gran Bretaña, en 1846 representaba tan sólo el 1,4\%. Las pasas, en cambio, se mantuvieron en torno al $10 \%{ }^{19}$.

El tráfico de estos productos estaba en manos de un pequeño grupo de comerciantes, entre los que figuraban en primer lugar una serie de apellidos extranjeros, especialmente por lo que se refiere al comercio de la barrilla y del vino (Cuadro 4). Aunque la barrilla estaba sufriendo un proceso de crisis debido a la competencia de otros productos, tradicionalmente había ocupado un lugar destacado en las exportaciones nacionales, llegando a alcanzar a finales del siglo XVIII el 2,6\% de éstas, en 1827 el 2,4\% ${ }^{20}$. En 1834 las exportaciones de barrilla alcanzaron un valor de 2,5 millones de reales, lo que suponía el 58,8\% del valor de todas las mercancías exportadas por el puerto de Alicante. En los años cuarenta el producto se hallaba en decadencia por la competencia de la sosa artificial, lo que había provocado un descenso importante de los precios, desde los 60-80 reales a los 20-24, y una caída de las exportaciones, un $46 \%$ entre 1835 y 1842 y un 53\% entre 1842 y 1843; de manera que en 1835 sólo aportaba el $0,9 \%$ del total y en $1842-1843$ el $0,2 \%{ }^{21}$. Sin embargo para el puerto de Alicante seguía siendo un producto fundamental, pues del total exportado en 1843 el 40\% salió de aquí2 ${ }^{22}$. Ante la situación de decadencia del producto los mercaderes ingleses asentados en Alicante pidieron al Gobierno británico en 1835-1836 que rebajara los derechos sobre la barrilla, a cambio de que el Gobierno español hiciera lo mismo con las manufacturas de lino irlandesas, las únicas que seguían utilizando la barrilla ${ }^{23}$.

La comercialización de los productos derivados de la vid estaba también principalmente en manos de las casas de comercio extranjeras El vino de Alicante gozaba de una buena demanda en el extranjero, debido a su calidad. Entre 1843 y 1844 se exportaron 38.470 arrobas, triplicándose casi la exportación entre un año y otro ${ }^{24}$.

Junto con la barrilla y el vino, la pasa era el otro gran artículo de exportación de la provincia. Este producto comenzó a despegar tras las guerras napoleónicas, como consecuencia del incremento de la demanda inglesa. El volumen de las exportaciones creció de forma espectacular, pasando de los 43.434 quintales en 1824 a más de

Nadal (1978), p. 233.

Prados (1984).

Los precios en Roca de Togores (1986 [1849]), las exportaciones en Fernández de Pinedo (1999), p.625 y Prados (1988), p. 202.

Fernández de Pinedo (1999) evalúa la barrilla exportada en 1843 en 47.950 quintales.

Nadal (1978), pp. 155-156.

La totalidad del vino exportado ascendió a 9.516 arrobas y la de barrilla a 19.104Qm. 
CUADRO 4

PRINCIPALES EXPORTADORES DE VINO Y BARRILLA EN 1843

\begin{tabular}{|c|c|c|c|c|}
\hline \multirow{2}{*}{ Exportador } & \multicolumn{2}{|c|}{ Vino $^{25}$} & \multicolumn{2}{|c|}{ Barrilla } \\
\hline & arrobas & $\%$ & quintales & $\%$ \\
\hline Salvetti y Harmsen & 1.459 & 15,33 & 3.950 & 20,67 \\
\hline J. Wallace & 533 & 5,60 & 892 & 4,66 \\
\hline G. White & 9 & 0,09 & 2.866 & 15,0 \\
\hline J. Bushell & & & 2.280 & 11,93 \\
\hline Waring y Cía. & 59 & 0,62 & 1.036 & 5,42 \\
\hline Carey y Cía. & & & 1.530 & 8,0 \\
\hline Satchel & & & 850 & 4,44 \\
\hline F. Sala & 936 & 9,83 & & \\
\hline A. Raimundo & 222 & 2,44 & & \\
\hline G. Duke & & & 450 & 2,35 \\
\hline F. Galiana & 210 & 2,20 & & \\
\hline J. Puigserver & & & 550 & 2,87 \\
\hline
\end{tabular}

Fuente: AHPA. Hacienda. Libro 215 y Madoz (1995), p.105

200.000 en 1840. En 1834 la pasa representaba el 20,14\% del valor total de las exportaciones agrarias valencianas, siendo la segunda partida en importancia tras la seda. Denia concentró el $84,1 \%$ del total. Las exportaciones se dirigían mayoritariamente a Gran Bretaña y en menor medida a Francia, norte de África y Estados Unidos, donde fue ganando cuota de mercado en la segunda mitad del siglo XIX ${ }^{26}$. A comienzos de los años cuarenta el comercio de la pasa entró en crisis coyuntural, como consecuencia de varios factores: en primer lugar, los altos aranceles que el producto debía pagar en Inglaterra - su principal destino-, que habían pasado de 25 reales por quintal en 1834 a 70 reales a mediados de siglo, por lo que encontraba la competencia de la pasa más barata de Esmirna y Corinto; en segundo lugar, la caída del consumo en Gran Bretaña; en tercer lugar, la peor calidad de la pasa de Denia frente a la de Málaga y Corinto; finalmente, el monopolio inglés en el comercio del producto, lo que permitía a los británicos controlar los precios, por eso era necesario la creación de "una sociedad española, con casas en Londres" ${ }^{27}$. Estas dificultades se tradujeron

\footnotetext{
25 Madoz (1995), pp. 156-157.

26 Morilla, Olmstead and Rhode (2000), pp. 199-232.

27 Citado por Costa (1977), p. 196. Piqueras (1985), p. 59.
} 


\section{CUADRO 5}

PARTICIPACIÓN EXTRANJERA EN LA EXPORTACIÓN DE PRODUCTOS AGRARIOS POR EL PUERTO DE ALICANTE

\begin{tabular}{|c|c|c|c|c|c|c|}
\hline \multirow{2}{*}{ Producto } & \multicolumn{3}{|c|}{1843} & \multicolumn{3}{|c|}{1844} \\
\hline & Nacional & Extranjera & Total & Nacional & Extranjera & Total \\
\hline Aguardiente (Arrobas) & 549 & 40 & 589 & 870 & 539 & 1.409 \\
\hline Almendra (Arrobas) & 3.251 & 4.800 & 8.051 & 294 & 7.753 & 8.047 \\
\hline Arroz (Arrobas) & 136 & - & 136 & 56 & - & 56 \\
\hline Anís (Arrobas) & 5.773 & 6.932 & 12.705 & 296 & 2.565 & 2.861 \\
\hline Azafrán (Libras) & 293 & 865 & 1.158 & 628 & 1.155 & 1.783 \\
\hline Barrilla (Quintales) & 391 & 18.713 & 19.104 & 609 & 20.395 & 21.004 \\
\hline Esparto (Quintales) & 4.790 & 4.264 & 9.054 & 6.804 & 2.678 & 9.482 \\
\hline Frutas (Cargas) & 4.227 & - & 4.227 & 1.029 & 1 & 1.030 \\
\hline Pasas (Arrobas) & 1.936 & 16.785 & 18.721 & 160 & 1.532 & 1.692 \\
\hline Pimiento (Arrobas) & 192 & - & 192 & 152 & - & 152 \\
\hline Regaliz (Quintales) & 2.023 & 1.238 & 3.261 & - & 971 & 971 \\
\hline Seda (Libras) & 128 & 43 & 171 & 280 & 20 & 300 \\
\hline Vino (Arrobas) & 3.743 & 5.773 & 9.516 & 7.706 & 21.148 & 28.854 \\
\hline
\end{tabular}

Fuente: Madoz (1995), pp.156-157

en una caída de las exportaciones que entre 1840 y 1844 se redujeron en un 9,1\%, para recuperarse al año siguiente y caer después, hasta 1848, un 243\%; mientras que para las mismas fechas las exportaciones del conjunto del país a Gran Bretaña subieron un $4 \% 28$. Por lo tanto, era necesario que el Gobierno adoptara las medidas necesarias para que los ingleses rebajaran los derechos de la pasa.

Como muestra el Cuadro 5, la participación extranjera en el tráfico de productos agrarios era relevante. En 1843 en torno al 68 \% de las exportaciones agrarias se realizaron en navíos de bandera extranjera y en 1844 supusieron el 75\%. Según Madoz frecuentaban el puerto principalmente buques ingleses, franceses, suecos, sardos, belgas, holandeses y norteamericanos; y existían representaciones comerciales de diversos países europeos - como Austria, Dinamarca, Gran Bretaña, Italia, Prusia, Suecia, Noruega, Bélgica, Francia o Portugal-y americanos, como Brasil o Estados Unidos ${ }^{29}$. La importancia de las compañías de comercio extranjeras queda

28 Roca de Togores (1986 [1849]), p. 178 y Nadal (1978), p. 348.
29 Madoz (1995), pp. 150-151. 


\section{CUADRO 6}

MAYORES CONTRIBUYENTES SEGÚN LA CONTRIBUCIÓN

DE GUERRA INDUSTRIAL DE 1841

\begin{tabular}{lcc}
\hline Contribuyente & Contribución en reales & $\%$ \\
\hline J. Wallace & 6.400 & 2,0 \\
Salvetti y Cía. & 6.400 & 2,0 \\
Roggerion y Cía. & 6.400 & 2,0 \\
Waring y Cía. & 6.400 & 2,0 \\
G. Duke & 5.700 & 1,8 \\
Bushell y Cía. & 5.700 & 1,8 \\
Carey y Cía. & 5.700 & 1,8 \\
Satchell y Cía. & 5.700 & 1,8 \\
Patterson y Cía. & 5.700 & 1,8 \\
J. Maisonnave & 5.700 & 1,8 \\
\hline
\end{tabular}

Fuente: AMA. Contribución de guerra industrial, 1841. Armario 7. Libro 94

atestiguada por el hecho de que en 1840 los primeros diez contribuyentes por industrial eran firmas extranjeras y aportaban el 19\% de la cuota (Cuadro 6).

Entre las importaciones, eran importantes los combustibles, los productos industriales y manufacturados como tejidos de lana y seda, maquinaria, material ferroviario, algodón, madera, bacalao. Los comerciantes alicantinos diversificaron notablemente sus puntos de suministro. Aunque predominaban con claridad las importaciones de Francia y Gran Bretaña — de donde procedían la mayor parte de los productos textiles y todo el material para el ferrocarril de Madrid a Aranjuez y para la instalación del gas en Madrid, lo que en 1847 supuso el 15\% del valor total de las importaciones - y de Terranova que suministraba todo el bacalao trasladado en barcos ingleses, los importadores adquirían sus mercancías de una amplia gama de países, sobre todo del norte y noroeste de Europa, o del Próximo y Extremo Oriente, si bien el comercio con estas regiones no se realizaba directamente, sino a través de los puertos británicos y franceses ${ }^{30}$. Especial importancia tenía el comercio del bacalao, cuya tradición se remontaba al siglo XVIII, a lo largo del cual Alicante monopolizó prácticamente el procedente de Terranova ${ }^{31}$. En general, este producto era una de las partidas más importantes en la estructura de las importaciones nacio-

$30 \quad$ AHPA, Hacienda. Libro 1394. Registro de aforos. 1847.
$31 \quad$ Giménez (1981), p. 367. 
nales, llegando a representar a finales del siglo XVIII el 5,7\% del total, el 3,5\% en 1827 y todavía en 1855 suponía el 3,9\%32. Entre 1843 y 1844 se importaron 154.250 quintales, la mayoría —el 92\% - en buques extranjeros. En 1847 las importaciones de bacalao alcanzaron un valor de 4.187 .562 reales, lo que representaba el 17,5\% del total. Este lucrativo tráfico estaba controlado por un pequeño grupo de 24 comerciantes entre los que se encontraban los principales representantes de la oligarquía de la ciudad, y todavía destacaba un pequeño núcleo de nueve o diez firmas comerciales que importaban más de la mitad.

El comercio con América también jugó un papel importante. Las exportaciones eran poco significativas, mientras que las importaciones supusieron durante los años cuarenta en torno al 25\% del valor total (Cuadro 7). Estaban constituidas fundamentalmente por azúcar, cacao, madera, quina, algodón, café, cueros y cera; pero destacaban el azúcar y el cacao, pues entre ambas partidas sumaban más del $90 \%$ del valor total (Cuadro 8) 33 . Como sucedía con el bacalao, la importación de azúcar estaba controlada por unos pocos comerciantes, pero en esta ocasión alcanzaba tan alto grado de concentración que de hecho constituía un oligopolio. Así, cuatro mercaderes, Antonio Campos, Jaime Maisonnave, Tomás España y Juan Bautista Caro importaban casi el 70\% del azúcar, mientras que treinta comerciantes importaban el resto.

En definitiva, existía una nómina de comerciantes relativamente amplia que mantenían relaciones mercantiles con numerosos puntos de Europa y con América, aunque la mayor parte del tráfico de importación estaba en manos de un pequeño grupo, pues cinco casas comerciales controlaban más de la mitad de las importaciones. La declaración de puerto de interés general en 1855 y la llegada del ferrocarril a la ciudad en 1858 potenciaron de forma notable la actividad mercantil, llegando a ocupar el puerto de Alicante en la segunda mitad de la centuria el sexto puesto, detrás de los de Barcelona, Sevilla, Valencia, Málaga y Cádiz ${ }^{34}$.

\subsection{El intento frustrado de crear una industria metalúrgica}

Agricultura y comercio no agotaban el universo económico de la burguesía alicantina. A comienzos de los años cuarenta hubo un intento de crear una industria de extracción de plata a partir del plomo, al socaire de una ley de 1840 que obligaba a fundir el mineral de plomo y extraer la plata que contenía ${ }^{35}$. El 15 de mayo de 1841

Prados (1984).

Madoz (1995), p. 153 y AHPA. Hacienda. Libro 1394. Registro de aforos. 1847.

El ferrocarril, en Díaz (2004), pp. 785-796. El puerto, en Frax (1981).

López Morell (2005), p. 109. 
CUADRO 7

VALOR DE LAS IMPORTACIONES (Reales)

\begin{tabular}{llll}
\hline & Extranjeras & Coloniales & Total \\
\hline $\mathbf{1 8 4 3}$ & 20.661 .821 & 7.081 .776 & 27.743 .597 \\
$\mathbf{1 8 4 4}$ & 21.533 .644 & 6.986 .569 & 28.520 .213 \\
$\mathbf{1 8 4 7}$ & 17.624 .334 & 6.305 .021 & 23.929 .355 \\
\hline
\end{tabular}

Fuente: Madoz (1995), AHPA Hacienda. Libro 1394

CUADRO 8

ESTRUCTURA DE LAS IMPORTACIONES DE AMÉRICA EN 1847

\begin{tabular}{lrrr}
\hline Producto & \multicolumn{1}{c}{ Cantidad } & Valor (reales) & $\%$ \\
\hline Azúcar & 125.855 arrobas & 4.836 .920 & 76,72 \\
Cacao & 149.487 libras & 896.922 & 14,22 \\
Madera & 5.023 quintales & 200.920 & 3,19 \\
Quina & 5.916 libras & 118.320 & 1,88 \\
Algodón & 425 quintales & 108.800 & 1,72 \\
Café & 225 quintales & 45.025 & 0,71 \\
Añil & 24 quintales & 36.000 & 0,57 \\
Otros & & 62.112 & 0,99 \\
\hline
\end{tabular}

Fuente: AHPA. Hacienda. Libro 1394

se constituyó la sociedad La Británica metalúrgica — cuya actividad era la fundición de metales-, compuesta mayoritariamente por capital inglés, pero también con presencia de capital nacional — por ejemplo Pita Pizarro, ministro de Hacienda en 1837 y 1838 , tenía participación en esta empresa ${ }^{36}$ - Se trataba de una sociedad con una duración prevista de 20 años y con un capital de 200.000 pesos fuertes (4 millones de reales) repartidos en 2.000 acciones de 100 pesos cada una ${ }^{37}$. Pronto salieron los primeros galápagos de plata de sus fundiciones ${ }^{38}$. En febrero de 1842 La Gaceta anunciaba la primera copelación de plata realizada por la fábrica consistente en 5.521 onzas y ocho adarmes y en julio de 1843 la empresa llevaba invertidos más de dos

\footnotetext{
36 Chastagnaret (2000), p. 373.

37 Jover (1863), p. 198.

38 La Gaceta, 16-2-1842.
} 
millones de reales en edificios, máquinas movidas por vapor y hornos. Los beneficios obtenidos se evaluaban en 600.000 reales, lo que hizo que esta sociedad fuese considerada como modelo de empresa eficiente por el presidente de la Junta Central de Minas, el socialista utópico Manuel Sagrario de Beloy ${ }^{39}$. El ejemplo cundió y en tres años surgieron otras fundiciones como La Alicantina, Las Palmas, San Juan o La Ratonera. Pese a que "todo el que poseía capital suficiente para comprar una acción" invertía, británicos y franceses no dejaron pasar la oportunidad de participar ${ }^{40}$. El representante de los Rothschild en Madrid, Weisweiller, se interesó muy pronto en el negocio de la copelación de plata y a través de la firma Antonio Campos e Hijo entró en contacto con las fundiciones. Los banqueros franceses prestaban a los fundidores a un interés que oscilaba entre el 9 y el $12 \%$, y a veces exigieron garantías hipotecarias sobre la propia fábrica. La necesidad de ampliar capital que tenían estas fábricas y su escasez les daban condiciones ventajosas. En 1842 la firma francesa Rodrigues Ely fils-aîné había contratado 200.000 onzas de plata, adelantando 40.000 pesos (800.000 reales) a un interés del $12 \%$ anual. El capital era reintegrable en la plata que se fuera copelando a razón de 23 reales la onza ${ }^{41}$.

Pero los Campos confiaban en que La Alicantina, en la que estaban interesados y deseaban, además, implicar a los Rothschild, se convirtiese en una de las primeras fábricas de Europa, para lo cual se habían traído técnicos y obreros cualificados ingleses y alemanes y se habían invertido a lo largo de 1842 dos millones de reales, por lo que esperaban que la plata fuera de mejor calidad que la de la Sociedad Británica ${ }^{42}$. Finalmente, tanto los Rothschild como los Campos acabaron comprometiéndose no sólo con La Alicantina, sino también con La Británica, empresa a la que Estanislao de Urquijo, enviado por Weisweiller a Alicante, entregó un anticipo de 75.000 libras a lo largo del mes de diciembre, del que los Campos hicieron efectivos 1.000, a cambio de la entrega de 200.000 onzas de plata en un plazo de siete meses a contar desde el 1 de marzo de 1843, fijándose una entrega mínima de 25.000 onzas mensuales $^{43}$. Pese a este esfuerzo las expectativas no se cumplieron y el negocio de la copelación fue efímero. Joaquín Roca de Togores habla de los elevados costes de producción, tanto de mano de obra, como de materias primas y transportes, pero sobre todo del carbón. Era necesaria una reforma arancelaria que abaratara su introducción ${ }^{44}$. El fracaso de las fundiciones supuso un coste de medio millón de duros, que recayó sobre los hacendados, los comerciantes, los menestrales, compradores de

Vilar y Egea (1990), pp. 52-53.

Jover (1863), p. 198.

Otazu (1987), pp. 147-149.

Otazu (1987), p. 149.

Otazu (1987), p. 158.

Roca de Togores (1986 [1849]). El carbón costaba en Alicante a 10,5 reales el Qm., y “a su carestía se debe atribuir una de las principales causas de la ruina de tantos capitales", p. 110. 
acciones de aquellas sociedades ${ }^{45}$. La economía alicantina se resintió de este desvío de capitales hacia las fundiciones, pues al quebrar éstas, escasearon "los fondos necesarios al cultivo de las tierras y a las especulaciones comerciales" ${ }^{\prime \prime 6}$. Esta debilidad financiera se evidenció también en la modesta participación del capital autóctono en la construcción del ferrocarril ${ }^{47}$. La burguesía alicantina reforzó así su opción agrarista y comercial.

\section{Estrategias económicas de la burguesía: Fomento de la agricultura e impulso al comercio mediante el librecambismo}

\subsection{Fomento de la agricultura}

En consonancia con la actividad económica que dominaba la ciudad, la burguesía comercial planteó en los años cuarenta del siglo XIX unas propuestas de crecimiento económico dentro de las coordenadas agraristas y librecambistas, una orientación que también tuvo cierto arraigo entre la burguesía urbana valenciana ${ }^{48}$. En 1846 y 1847 se publica en Alicante El Mensajero, órgano de la Compañía Alicantina de Fomento fundada en 1846, cuyos intereses eran defendidos en Madrid por el Diario del Comercio. La Compañía fue creada por un grupo de hacendados y comerciantes con el triple objetivo de establecer cajas de ahorros y de seguros, proporcionar crédito a labradores y artesanos y fomentar el desarrollo económico de la provincia ${ }^{49}$. El director gerente era un abogado y comerciante, Juan María Vignau, y el inspectorfundador, Pedro Lara, cuya relación con la economía alicantina venía de tiempo atrás, pues en 1843 había presentado un proyecto al Gobierno para construir una línea férrea entre Madrid y Alicante ${ }^{50}$. El semanario alicantino contaba como principal colaborador con Balbino Cortés, un destacado agrarista admirador de A. Smith y J. B. Say, que entre 1856 y 1858 ocupó la secretaría del Real Consejo de Agricultura, Industria y Comercio; escribió algunos opúsculos —Manual del cultivador del lino y cáñamo, Salvación de las viñas o historia del oidium-tuckeri, y de los métodos empleados hasta el día para preservarlas de esta enfermedad- y numerosos artículos sobre temas agrarios en diversas publicaciones como el Diccionario de Agricultura práctica y economía rural dirigido por Agustín Esteban Collantes y Agustín Alfaro, el Boletín Oficial

\footnotetext{
$45 \quad$ Jover (1863), p. 198.

46 Roca de Togores (1986 [1849]), p. 110.

47 Jover (1863).

$48 \quad$ Romeo (1992), p. 35.

49 El Mensajero, 31-12-1846.

50 Díaz (1998b), pp. 81-108.
} 
del Ministerio de Fomento, o la Revista Mensual de Agricultura ${ }^{51}$. Su interés por la agricultura no era sólo teórico, también adquirió diversas propiedades desamortizadas por valor de 77.000 reales en Alicante, Mutxamel y Villajoyosa ${ }^{52}$.

En esta publicación se diseña un modelo de crecimiento económico que engarza con la tradición establecida por Say, y seguida por Bastiat, caracterizada por el optimismo y la confianza en las posibilidades de desarrollo material y moral mediante la instrucción y el impulso del proceso productivo ${ }^{53}$. Además de los obstáculos legales que podían oponerse al progreso agrario, los aspectos técnicos de la agricultura eran cuestiones que cada vez preocupaban más al pensamiento agrarista, que desarrolla un discurso destinado a implicar más a las élites, a los propietarios, en la gestión directa de sus patrimonios y en la difusión de los conocimientos agronómicos. La introducción de nuevas plantas, la alternancia de cosechas, la construcción de pozos artesianos, la innovación técnica, la ampliación del regadío eran cuestiones que preocupaban a las élites y sobre las que aparecen artículos en El Mensaje$r o^{54}$. La demanda del trasvase del Júcar para regar la Huerta de Alicante ${ }^{55}$, la aclimatación de nuevas plantas — como el nopal—, los ensayos con el arado Dombasle en Orihuela, Elche y Alicante o el trillo americano que se probó en la hacienda modelo del conde de Pinohermoso ${ }^{56}$, la combinación de productos clásicos —cereal, vino, aceite - de fácil salida al mercado, con otros nuevos — alfalfa, higos, guisantes- cercanos a una agricultura modernizada son muestras del interés de las élites en ser protagonistas en el desarrollo agrario ${ }^{57}$.

El crecimiento demográfico había creado nuevos retos a la agricultura que tenía que procurar manutención a la población, para lo cual debía renovarse, orientarse al mercado y especializarse en productos que tuvieran fácil salida, diversificando la producción, pues no había que "aspirar a dar panes solamente" ${ }^{28}$. La moderna agricultura debía basarse no sólo en los conocimientos acumulados por la experiencia, también había de tener en cuenta las aportaciones de la ciencia, que permitirían un incremento de la productividad mediante un uso intensivo del suelo y la alternancia de cosechas. Pero había que contar con la resistencia al cambio de los cultivadores, pues "todo el mundo sabe que no hay clase más opuesta a innovaciones que la que trabaja en el campo" ${ }^{\prime 59}$. Este agrarismo tenía un carácter antiindustrialista. La preferencia

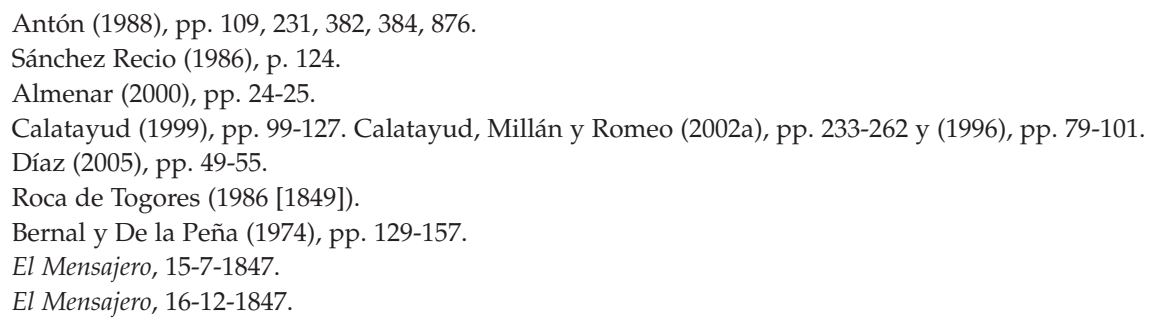


por la agricultura se debía no sólo a las ventajas comparativas del sector frente a la industria, sino también a las negativas consecuencias sociales derivadas de la industrialización ${ }^{60}$. En efecto, tras mostrar una cierta admiración por la política económica desarrollada en Inglaterra, Balbino Cortés criticaba el sistema industrial inglés por sus implicaciones sociales, por la sobreexplotación del trabajo asalariado ${ }^{61}$.

En El Mensajero se señalaban los obstáculos que dificultaban el desarrollo del sector:

1) El sistema educativo español no fomentaba el estudio de las ciencias aplicadas, lo que determinaba la escasez de técnicos. España debía adaptar la enseñanza a los nuevos tiempos, para formar los profesionales que demandaba la sociedad burguesa y superar la dependencia tecnológica del país con respecto al extranjero. Se insistía en la idea ilustrada, expuesta entre otros por Jovellanos, de los perjuicios derivados del abandono de la enseñanza de la agricultura como ciencia ${ }^{62}$. Los labradores debían estudiar la ciencia agrícola, conocer las calidades de las tierras, destinarlas al producto más idóneo y conseguir un aumento de la producción y de la productividad, así como una especialización ventajosa en el mercado. Para ello, se necesitaba la protección de los poderes públicos, responsables de crear canales de financiación y fomentar el asociacionismo entre los cultivadores, de manera que se pudieran transmitir sus experiencias. Los ayuntamientos también debían financiar cursos de agricultura práctica en las escuelas a través de sus bienes de propios, para que los niños pudieran adquirir desde muy jóvenes conocimientos agronómicos, así se respetaría más el medio y se evitaría el éxodo a las ciudades. Se podrían crear haciendas modelo, donde se experimentara la introducción de nuevos cultivos más rentables ${ }^{63}$. Este tipo de propuestas, aunque no se concretaron en un apoyo decidido del Estado a la enseñanza agraria, al menos contribuyeron a crear un cierto clima de preocupación en las instituciones sobre estas cuestiones ${ }^{64}$.

El Mensajero, 25-2-1847. Dada la fertilidad del suelo y del clima-opinaba el semanario- "nuestras producciones son de más cuantía que las que por el trabajo mecánico no conseguiremos tal vez jamás". Este optimismo agronómico ya se observa en Flórez Estrada, partidario de la primacía de la agricultura frente a la industria, Almenar (1976), pp. 58-81. José Joaquín de Mora opinaba que las ventajas de la agricultura residían en las "excelencias de nuestro suelo y de nuestro clima", citado por Velasco (1990), p. 85. El Mensajero, 25-2-1847. Para reducir costes y aumentar la tasa de beneficios, los manufactureros ingleses "inventaron máquinas que reuniendo fuerza y economía reemplazase una sola infinidad de operarios, y pareciéndoles hasta caro el jornal que a los pocos empleaban, los sustituyeron con mujeres y también con criaturas de pocos años. No pareciéndoles suficientes estos recursos, avanzaron hasta los límites de lo imposible, bajando el salario sin consideración alguna... Cuanto quisieron hacer, otro tanto hicieron sin impedimento alguno, y desde el momento en que éstas eran las bases del sistema industrial en Inglaterra, no hubo entonces más que amos y esclavos".

62 Jovellanos (1945), pp. 58-64. Sobre estas cuestiones, Argemí y Lluch (1985).

63 El Mensajero, 10-12-1846; 21-1-1847, 4-2-1847, 18-3-1847, 1-4-1847, 18-11-1847.

64 Fernández (1998), pp. 237-286. 
2) La excesiva carga fiscal soportada por los propietarios, que empujaba al "abandono del cultivo de muchos terrenos", incluso ponía en peligro su posesión, al verse obligados sus dueños a venderlos por no poder financiar los costes de su explotación, aunque la historiografía actual considera que la presión fiscal sobre la agricultura no era excesiva. Pero no sólo los propietarios soportaban la contribución territorial, pues muchos trasladaban esta carga a los arrendatarios ${ }^{65}$, más numerosos en la huerta de Orihuela y en los distritos de las montañas ${ }^{66}$. A ello había que añadir la contribución de consumos y los derechos de puertas. Estas exacciones disminuían el consumo con lo que el exceso de oferta podía provocar la caída de precios hasta niveles no remuneradores para el agricultor. Los derechos de puertas debían ajustarse y tener en cuenta "la pobreza de ciertas clases de consumidores", de manera que la demanda pudiera relanzarse proporcionando beneficios a los productores y un aumento de los ingresos para las arcas públicas ${ }^{67}$. En definitiva, un gravamen más realista podría ser más beneficioso para el país al armonizar los intereses de la Hacienda pública, de los productores y de los consumidores. Sin embargo, cuando los comerciantes ocupaban las concejalías no pusieron en práctica la reducción de impuestos indirectos para fomentar el consumo, antes al contrario, una parte importante de los ingresos municipales provenía precisamente de los consumos. De hecho, durante la Década Moderada, más del 60\% de los ingresos presupuestados para cubrir el déficit de la hacienda municipal procedía del recargo sobre los consumos ${ }^{68}$.

3) La carencia de buenas vías de comunicación, que impedía una nivelación de precios. En años críticos como 1847 las oscilaciones del precio del trigo en algunas regiones con respecto al promedio nacional podían llegar al 30\% o más ${ }^{69}$.

4) El carácter incompleto de la reforma agraria liberal. Los gobiernos liberales habían tomado medidas para favorecer el crecimiento agrario, como la desamortización o la desvinculación; sin embargo, la "enajenación no ha llegado a su término como lo exigía el espíritu de la época, y aun el verdadero y bien considerado interés del fisco" ${ }^{\prime 70}$. Por otro lado, los efectos sociales de la reforma agraria no habían sido los deseables, pues no había repercutido positivamente sobre los grupos a los que intentaba favorecer, en clara alusión a la propuesta de Flórez Estrada. No se había creado una sociedad de pequeños y medianos propietarios, aunque esto era difícil de realizar a partir únicamente de los bienes de la iglesia ${ }^{71}$.

65 Vallejo (2001).

66 "Contestación de la Junta de Agricultura de la provincia de Alicante al interrogatorio o encuesta agrícola de 1849", en Vidal (1986), pp. 183-189.

67 El Mensajero, 28-2-1847.

68 Díaz (1998a), p. 370 y Salort (1998).

69 Díaz (2003), pp. 31-62 y (2007), pp. 267-292.

70 El Mensajero, 21-1-1847.

71 Millán (2000), pp. 181-211. 
5) La escasa capitalización del sector. La falta de capital obligaba al cultivador a buscar dinero prestado consiguiéndolo a un interés demasiado oneroso. Los pósitos podían ser un recurso, pero estaban en decadencia. Los poderes públicos debían promover la formación de asociaciones agrícolas que pudieran ayudar a los agricultores en un momento de apuro. Al mismo tiempo, era necesario crear instituciones de crédito agrícola. La Junta de Agricultura insistía en la necesidad de establecer Bancos de Socorros mutuos o Bancos Agrícolas "para arrancar a los agricultores del dominio de los usureros"72. Joaquín Roca de Togores, el comisionado regio del Ministerio de Comercio para la provincia de Alicante, cifraba el interés del dinero entre un 20 y un $40 \%{ }^{73}$, aunque el tipo de interés dependía de la escala sociolaboral del prestatario, siendo más alto cuanto más bajo se encontraba en esa escala ${ }^{74}$. La creación en 1846 de la Compañía Alicantina de Fomento, especializada en el crédito, el ahorro y los seguros de quintas, no solucionó el problema; y la falta de instituciones de crédito de carácter organizado dio protagonismo al crédito privado ejercido por los grandes comerciantes y propietarios ${ }^{75}$.

6) La errónea política comercial que se traducía en la falta de buenos tratados de comercio capaces de abrir mercados exteriores.

\subsection{Impulso al comercio. Librecambismo y tratados comerciales}

La burguesía mercantil opinaba que el crecimiento económico exigía la adopción por parte del Gobierno de medidas de carácter librecambista. Como sucedió con otras burguesías periféricas ${ }^{76}$ - aunque, tal vez, de forma menos sistemática- los mercaderes alicantinos manifestaron su opinión bien a través de exposiciones al Gobierno, bien a través de la prensa. Esas ideas las hicieron públicas en forma de polémica con los principales defensores del proteccionismo, los industriales algodoneros catalanes, quienes, junto con los productores de trigo terminaron por convertirse en un grupo de presión eficaz que pudo frenar los intentos reformadores del sistema prohibitivo en materia de algodones, defendiendo una política económica que reservara el mercado interior a los géneros de algodón del Principado y a los cereales nacionales ${ }^{77}$.

\footnotetext{
72 "Contestación de la Junta de Agricultura de la provincia de Alicante al interrogatorio o encuesta agrícola de 1849", en Vidal (1986), p. 188.

Roca de Togores (1986 [1849]), p. 107.

Cuevas (2001), pp. 89-120.

Cuevas (2001), pp. 89-120. En la Vega Baja los colonos también dependían del crédito privado, Millán (1999). Sobre el crédito en el regadío valenciano, Calatayud, Millán, Romeo (2002b), pp. 375-398. Hernández (1996), pp. 196-215.

76 Montañés (2007), pp. 459-483.

77 Sánchez (2000), pp. 485-523.
} 
Mariano Miguel de Reinoso, comisario regio para la inspección general de la agricultura del reino, se alineaba con los fabricantes catalanes y pedía al Gobierno "protección para el trabajo nacional", es decir, "restricción para el que tenemos joven; y prohibición para el que tenemos naciente" 78 .

La burguesía alicantina consideraba la libertad de comercio como uno de los elementos fundamentales del desarrollo económico, y la incluía en una concepción más amplia de la libertad económica cuya base era la libre concurrencia de los diferentes agentes económicos en el mercado, con las menores restricciones posibles impuestas por el intervencionismo estatal. De ahí su defensa de un mercado interior libre de trabas y de un mercado exterior no limitado en exceso por medidas proteccionistas. Las rentas estancadas, los monopolios de la sal y del tabaco y la excesiva carga fiscal eran elementos que limitaban y distorsionaban el mercado interior y frenaban el crecimiento $^{79}$. De la libertad de comercio se derivaban también implicaciones políticas, ya que "el Gobierno que coarta el comercio por medio de prohibiciones, pone trabas a su propia libertad" 80 . Además, con la libertad de comercio aumentaba la riqueza nacional, la economía se hacía más competitiva y el Estado recaudaba más. El librecambio era contemplado "como el remedio universal de todos los males de la patria" ${ }^{\prime 1}$. Por el contrario, las limitaciones a la importación, al poner trabas a la libre competencia, favorecían la tendencia al monopolio, la subida de precios y la reducción de la oferta a corto plazo. Los precios altos retraían el consumo, provocando a la larga una saturación del mercado, que obligaría a cerrar fábricas y haría aumentar el paro. Así, el argumento librecambista tenía en cuenta el punto de vista del consumidor $^{82}$.

Las importantes relaciones de la economía alicantina con el exterior, a lo que contribuía la presencia de casas de comercio extranjeras, probablemente influyeron en la demanda de aranceles más suaves. En la línea propugnada por Flórez Estrada los comerciantes apostaron por una política librecambista vinculada a la agricultura de exportación ${ }^{83}$. Cuando, durante la Regencia de Espartero, surgió la posibilidad de firmar un tratado comercial con Gran Bretaña, la Diputación presentó el 20 de agosto de 1841 una exposición al regente trasladando los deseos de los comerciantes y cosecheros de pasa de la provincia de que se rebajaran los aranceles que recargaban los productos ingleses, para que la pasa alicantina obtuviera igual trato en los mer-

Informe presentado a las Juntas Generales de Agricultura de 1849 por su comisión novena, sobre las causas que contribuyen a que muchas de nuestras producciones agrícolas sean más caras que las de otras naciones (1849).

El Mensajero, 22-4-1847.

Ibídem.

Schwartz (1999), p. XV.

Almenar (1976), p. 63.

Almenar (1980), pp. XXXV-CXXIII.
} 
cados británicos y pudiera competir con la de otras zonas del Mediterráneo. La Diputación sugería que se ampliase el consumo de pasa a todas las clases sociales, y no sólo a las clases altas, lo que repercutiría en un aumento de la demanda. Al mismo tiempo pedía el fin del prohibicionismo, "a cuya sombra crecen el vicio, la inmoralidad y los abusos" 14 . Poco antes se había pronunciado en el mismo sentido la Sociedad Económica de Amigos del País de Cádiz, que - preocupada por los efectos de la política comercial sobre la economía andaluza - en una exposición dirigida a la Regencia provisional, pedía la reforma del sistema prohibitivo y el establecimiento de un gravamen sobre las manufacturas extranjeras de un 50\% máximo y concluía que si en estas condiciones la industria nacional no podía competir con la extranjera, no debía mantenerse a expensas de los consumidores y de los intereses del país ${ }^{85}$.

Durante la tramitación parlamentaria del arancel de 1841, Joaquín María López, asiduo representante de la provincia en las Cortes - aunque en aquella legislatura había optado por Valencia ${ }^{86}$ — tachó de mezquino el prohibicionismo, si bien reconocía que, por cuestiones de oportunidad, había que tener también presentes los intereses de Cataluña ${ }^{87}$. El arancel entró en vigor sin satisfacer los anhelos librecambistas de los exportadores alicantinos; de hecho, la reforma arancelaria aprobada en el Congreso el 14 de junio no contó con ningún voto favorable de los diputados de la provincia: algunos no acudieron al Congreso y dos votaron en contra ${ }^{88}$. El 3 de octubre los propietarios de viñas y agricultores de Alicante y Menorca volvían a plantear la misma cuestión, ponían el acento en el estancamiento de la agricultura a causa de los altos aranceles con que Gran Bretaña gravaba la uva moscatel y solicitaban la apertura de negociaciones con este país para que rebajara los impuestos a cambio de ciertas concesiones. El embajador británico confiaba más en declaraciones como la de Alicante que en una negociación directa con el Gobierno español para introducir modificaciones en el sistema de comercio $^{89}$. El asunto era importante, pues en 1842-1843 el valor de la pasa exportada representaba el 5,7\% del total de las exportaciones ${ }^{90}$. Las demandas de la burguesía alicantina se intensificaron a comienzos de 1842, cuando el embajador británico presentó al Gobierno español el borrador

BOPA, 22-8-1841.

Memoria (1841).

Díaz (2002). En la elección de Tomás Comyn como senador por la provincia de Alicante en 1843 pudo influir el hecho de que formara parte de la comisión que nombró el gobierno para estudiar la propuesta británica y que presentó un proyecto bajo el principio de una "estricta y racional reciprocidad", Lafuente (1922), pp. 132-134.

Diario de Sesiones de las Cortes, Congreso 12-6-1841 (DSC en adelante). Los debates parlamentarios en Gómez (2002) y Montañés (2007), pp. 459-483.

DSC, 14-6-1841. El papel de las élites políticas en el movimiento librecambista en Sánchez León (1999).

Rodríguez (1985), p. 349.

Prados (1988), p. 202. 
de un tratado comercial que rebajaba los derechos de algunos productos españoles, a cambio de que el ejecutivo levantara la prohibición sobre los tejidos de algodón, pues el arancel aprobado en 1841, aunque redujo las prohibiciones de 653 a 94, no incluyó ni los cereales ni los algodones, si bien su artículo tercero dejaba la puerta abierta a que se completara en la siguiente legislatura. Eso fue lo que pidió el diputado Manuel Sánchez Silva mediante una interpelación presentada en el Congreso el 6 de abril de $1842^{91}$.

Aunque el Gobierno había previsto el año anterior indemnizar a Cataluña de los perjuicios que pudiera acarrearle la competencia extranjera, destinando a ello una parte del aumento de la renta de aduanas que se esperaba conseguir con el incremento del tráfico mercantil ${ }^{92}$, los fabricantes catalanes, a través de sus representantes en el Congreso, se opusieron a la pretensión británica, mientras que la Junta de Comercio y la Diputación alicantinas se alinearon con las posiciones de los exportadores de vino andaluces ${ }^{93}$ y presentaron el 28 de junio de 1842 una exposición al Regente solicitando la adopción de una política más librecambista, vinculada a la firma de un tratado de comercio con Gran Bretaña ${ }^{94}$. Las instituciones alicantinas consideraban que el sistema prohibitivo había sido uno de los errores más funestos de cara "al desarrollo de la civilización y a la prosperidad de las naciones". Insistían en que poco a poco se iba consolidando la idea de la conveniencia de la libertad mercantil y manufacturera, pues la experiencia había demostrado la positiva influencia de la libertad de tráfico y de industria en la prosperidad de un país; mientras que, por el contrario, el intervencionismo mercantilista del Estado no había favorecido el desarrollo económico. Y recordaban que las Cortes de 1812 habían terminado con los privilegios y levantado las trabas al comercio interior y a la agricultura; y que el absolutismo de Fernando VII, "que se complacía en destruir con ingratitud todo cuanto provenía de la representación nacional", tuvo que respetar la libertad de tráfico interior.

Si la libertad de comercio interior constituía una de las bases de la prosperidad del Estado, los mismos resultados se podían obtener cuando se trataba del comercio internacional. Al fin y al cabo, para el liberalismo económico, siguiendo la estela de Smith y Say, no existía diferencia entre el comercio nacional y el internacional ${ }^{95}$. Este era un principio económico básico y, aunque las circunstancias no aconsejaban su aplicación de un modo absoluto, el sistema de comercio más idóneo sería el que menos se alejara de esa libertad absoluta. La Diputación y la Junta de Comercio hacían suyo

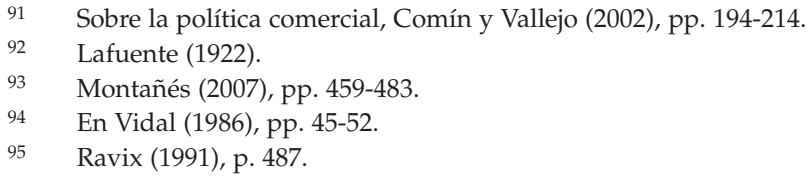


este principio para emitir su opinión sobre la conveniencia de admitir las manufacturas inglesas y aportaban otros que evocaban las razones esgrimidas por Pebrer en favor del librecambio ${ }^{96}$.

En primer lugar, la industria catalana no se destruiría con la admisión de algodones y otras manufacturas extranjeras. Al contrario, la competencia despertaría entre los fabricantes catalanes la necesidad de perfeccionar sus métodos de fabricación. En la provincia de Alicante existía el ejemplo de Alcoy, cuya industria no había quedado destruida por la entrada de paños extranjeros ${ }^{97}$. Sería, por tanto:

“un agravio para los catalanes suponerles con una limitación tal de facultades que no sean capaces de nivelar su industria con la de los pueblos hoy más aventajados, imitando a nuestros fabricantes de paños y de otros efectos que progresan sin necesidad de las prohibiciones" ${ }^{\prime \prime 9}$.

Pero, al mismo tiempo, reconocía que también era necesaria una cierta protección para esta industria, pues lo cierto era que la manufactura algodonera no resultaba competitiva en los mercados internacionales. La historiografía actual señala la relación entre esta falta de competitividad y los altos niveles de protección, que determinó que la industria catalana no se especializase en productos donde podía tener ventaja comparativa, al tener asegurado el mercado interior ${ }^{99}$. En segundo lugar, los intereses de Cataluña no se basaban exclusivamente en la industria algodonera; también eran actividades importantes la producción y exportación de vinos. En tercer lugar, el Gobierno no debía sacrificar los intereses de la mayoría a los de la minoría. La industria catalana no era el sector que más contribuía a la formación de la renta nacional, sino la agricultura; pero la dinámica agricultura de la periferia litoral se vería amenazada si sus producciones no tuvieran salida. Las provincias del interior también se beneficiarían, podrían colocar en el mercado inglés productos como azafrán, cominos, anís, lanas, y ponerse en el camino de la prosperidad, pues "exclusivamente dedicadas al cultivo de cereales, no hay que esperar progresen en su agricultura mientras el Gobierno no facilite los medios de exportación". El sistema prohibitivo debía desaparecer. Proteger un ramo de la riqueza a costa de los demás era un absurdo, pero insistir en sacrificar los intereses de la agricultura en beneficio exclusivo de la industria era, además, una injusticia — los exportadores alicantinos obviaban intencionadamente las ventajas que el proteccionismo reportaba a

\footnotetext{
96 Almenar (2000).

97 Sobre la industria alcoyana y su capacidad de adaptación a los mercados Torró (2001), pp. 147-166. Cuevas (2000), pp. 77-108.

$98 \quad$ En Vidal (1986), p. 47.

99 Rosés (2001), pp. 85-109.
} 
la agricultura cerealista ${ }^{100}$ - Finalmente, el sistema prohibitivo fomentaba el contrabando, cuya práctica tenía un triple efecto negativo: corrompía la moral pública, reducía la renta de aduanas y aumentaba el presupuesto de gastos del Estado con el coste del resguardo marítimo.

En aras de la prosperidad nacional, consideraba la burguesía alicantina, el Gobierno debía abrir el mercado interior a las manufacturas inglesas. Además, la industria nacional también prosperaría si las materias primas y la maquinaria obtuvieran una rebaja en las aduanas, aunque el arancel de 1841 ya había reducido los derechos sobre productos siderúrgicos destinados al mercado agrario y establecía tarifas muy bajas para la maquinaria extranjera ${ }^{101}$. Las instituciones alicantinas rechazaban el librecambismo radical y se inclinaban por un proteccionismo moderado y selectivo que abriera al mismo tiempo mercados a los productos agrícolas. Era una posición acorde con la diversidad de intereses existente en el seno de la burguesía, que podría perder mercados como el catalán, a donde enviaba importantes cantidades de trigo, de aplicarse un librecambismo más radical. La burguesía alicantina se situaba en la línea de otras burguesías periféricas, como la malagueña ${ }^{102}$.

La cuestión algodonera quedó sin resolver, y a partir de 1845 se fue gestando la reforma que culminó en el arancel de 1849, que reducía las prohibiciones de 94 a 14 . En enero de 1847 se hizo cargo del Ministerio de Hacienda Santillán y el 5 de febrero nombró una Junta de aranceles de perfil claramente proteccionista ${ }^{103}$. Formaba parte de ese Gobierno Mariano Roca de Togores, diputado por la provincia de Alicante, que había sido puesto al frente del recién creado Ministerio de Comercio, Instrucción y Obras Públicas ${ }^{104}$. Roca de Togores creía necesario remover la cuestión arancelaria y por Real Decreto de 4 de marzo de 1847 creó una Junta de información para responder a un cuestionario sobre cereales, algodones y otras industrias, formada por expertos nombrados por el Ministerio de Hacienda y representantes de las Juntas de comercio y de las Sociedades económicas ${ }^{105}$. La Junta de información quedó constituida el 27 de marzo, y fue incluido en ella Joaquín Roca de Togores persona muy vinculada a los intereses alicantinos y hermano del ministro ${ }^{106}$ - . A lo largo de los meses de mayo y junio las distintas comisiones fueron presentando sus dictámenes a la Junta de información. La Comisión tercera, que se ocupaba de la

Llopis (2002), p. 194. Gallego (2005), pp. 263-285, matiza más la influencia del proteccionismo en el desarrollo agrario.

Sáez (2004), p.186.

Velasco (1990), pp. 123-133.

Comín y Vallejo (2002), pp. 202 y 419.

Díaz (1998a), pp. 199-202.

La Gaceta, 6-3-1847.

La Gaceta, 28-3-2847. 
industria algodonera, presentó dos dictámenes diferentes. La división primera, presidida por Madoz, propuso mantener la prohibición sobre la mayoría de los tejidos de algodón ${ }^{107}$; mientras que la división segunda, de la que formaba parte Manuel Sánchez Silva, propuso un proteccionismo gradualista que fuera reduciendo paulatinamente los derechos de importación hasta que en 1852 los que gravaban los hilados de algodón no superasen el 15\% y los de los tejidos del mismo género el 25\%108.

En este contexto, políticamente distinto, de nuevo volvieron a tomar fuerza entre la burguesía alicantina las ideas librecambistas. Su principal difusor fue El Mensajero, además de un precoz divulgador de la obra de Bastiat, cuyos Sofismas Económicos habían sido traducidos por Ángel Justo Pasarón y publicados en El Amigo del País entre el 27 de enero y el 6 de octubre de 1847 —probablemente de donde los toma el semanario alicantino, que publica el primer texto de Bastiat el 4 de febrero-. El economista francés consolidaba su influencia en el pensamiento económico español ${ }^{109}$.

Así pues, la presencia de Roca de Togores en el Gobierno, de quien esperaban que trajera la prosperidad a la provincia ${ }^{110}$, propició esta nueva campaña de los comerciantes alicantinos; pero también influyó el abandono del proteccionismo agrario por Inglaterra con la abolición en 1846 de las corn laws, favoreciendo el impulso del movimiento librecambista, que contaba para su difusión con la Confederación Mercantil Española fundada ese mismo año, a la que se asociaron algunos comerciantes alicantinos y alcoyanos ${ }^{111}$. Además, en 1847 se activó la polémica entre proteccionistas y librecambistas con motivo de la circular del Gobierno de 14 de marzo prohibiendo la extracción de cereales al extranjero para remediar la crisis de subsistencias que afectaba al país y que estaba provocando una oleada de motines ${ }^{112}$.

En un artículo titulado "Palinodia dedicada al Semanario de la Industria", El Mensajero ironizaba:

“iPerdonad, hombres ilustres! que por un momento haya creído que el interés de 14 millones de consumidores que desean comprar barato y bueno, pueda pesar en la balanza contra el de 100 o 200 dueños de fábricas que conocen mejor nuestros intereses y ven prácticamente que nuestra felicidad consiste en comprarle caro a ellos"113.

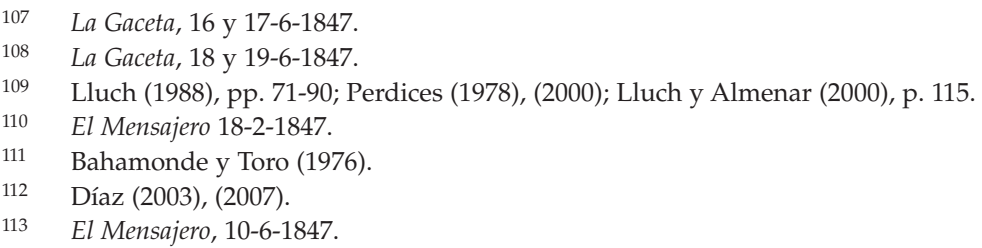


Por lo tanto, la burguesía alicantina era de la creencia de que el prohibicionismo iba en contra de la libertad, del interés y del bienestar de toda la nación ${ }^{114}$, frente a la opinión manifestada por los fabricantes catalanes que presentaban la industria como el verdadero motor de la economía, y el prohibicionismo como el único sistema capaz de impulsar el desarrollo económico, asegurar la tranquilidad social y la estabilidad política $^{115}$. En general -insistía El Mensajero-, la protección a la industria iba en detrimento de la misma industria, pues la falta de competencia, además de bajar la calidad del producto, propiciaba la subida de precios ${ }^{116}$. En su Memoria Joaquín Roca de Togores aprovechaba la ocasión para alentar al Gobierno y a las Cortes a que tuvieran en cuenta — en la línea de un librecambismo más matizado- que:

"la reciprocidad de derechos hace que solo abriendo al comercio extranjero nuestros puertos, y admitiendo todos sus productos, aunque con algunos derechos protectores, es como conseguiremos sean los nuestros recibidos sin los crecidos gastos que ahora tienen"117.

En cualquier caso, el libre comercio era entendido casi como un derecho natu$\mathrm{ral}^{118}$, pero su defensa no se concretó en un movimiento asociacionista que lo potenciara. La Asociación Mercantil Española creada en Cádiz en noviembre de 1846 podía ser un ejemplo a seguir, y a ello animaba El Mensajero ${ }^{119}$. No fue así, de lo que pocas semanas después se lamentaba el mismo periódico ${ }^{120}$. Pese a sus deseos, la apatía y la indiferencia, continuaron siendo las notas dominantes en materia de asociacionismo. Ni siquiera la visita de Richard Cobden a Alicante favoreció el movimiento asociacionista. Invitado por el cónsul inglés, Cobden llegó a la ciudad a finales de 1846. No parece que su estancia tuviera especial relevancia. Se dedicó a visitar la colección de pinturas del marqués de Algorfa y llamaron su atención las pasas, el turrón y la deficiencia del sistema de riegos ${ }^{121}$.

\footnotetext{
114 El Mensajero, 22-4-1847.

115 Sánchez (2000).

116 El Mensajero, 22-4-1847.

117 Roca de Togores (1986 [1849]), p. 109.

118 Almenar (2000), p. 54.

119 El Mensajero, 4-2-1847. “Nosotros rogamos a nuestra junta de comercio, a la sociedad económica alicantina, y en fin al comercio en general, el que tomen por base estos principios de asociación comercial y establezcamos en nuestra capital una que... promueva la gran regeneración de nuestros intereses comerciales y de nuestra industria".

120 El Mensajero, 1-4-1847.

121 Lluch (1988), pp. 71-90.
} 


\section{Conclusiones}

A mediados del siglo XIX la ciudad de Alicante estaba controlada por una élite de propietarios y comerciantes, que conjugaban diversas actividades económicas, como la agricultura, el comercio, el crédito o la hostelería. Pero la principal actividad era la mercantil, que condicionaba a su vez una orientación claramente comercial de la agricultura. La presencia de una importante colonia de mercaderes extranjeros con importantes conexiones con Francia y Gran Bretaña otorgaba un carácter todavía más abierto a la actividad económica. Este panorama potenciaba unas élites dinámicas, comprometidas con el crecimiento económico, atentas no solamente a las oportunidades del mercado, sino también a la coyuntura política.

El discurso económico de esta burguesía, con una importante presencia de hacendados nobles, se perfiló como agrarista y librecambista, dos variables de un mismo binomio. Como en otras ciudades de la periferia, aunque con diferencias de énfasis - tal vez por su diversidad de intereses-, vinculaban el crecimiento económico a la expansión de una agricultura intensiva, renovada e inserta en el mercado. Conscientes de que el fomento de la competencia era una cuestión política, para estos comerciantes y propietarios eran muy importantes las decisiones que en materia comercial pudieran tomarse desde Madrid, de ahí que intentaran influir en éstas de dos maneras: por un lado, enviando a las Cortes a representantes comprometidos con las ideas librecambistas; por otro, mediante exposiciones al poder ejecutivo y la financiación de una prensa periódica que difundiera las ideas del librecambio, al que le otorgaban una significación más allá que la meramente económica, pues lo asimilaban a la consolidación del liberalismo político. Fue precisamente en los momentos en que se planteó la posibilidad de reformar los aranceles en la dirección de restringir el prohibicionismo en 1841-1842 y 1846-1847, cuando esta burguesía, que no fue capaz de crear un grupo de presión consistente, reclamó al Gobierno la liberalización del comercio exterior mediante una rebaja de los aranceles y la firma de un tratado comercial con Gran Bretaña. Sin embargo, la burguesía fue matizando sus demandas de liberalización comercial, pues sus pautas económicas debían tener en cuenta la diversidad de intereses existentes en su seno. En este sentido no había que olvidar las crecientes relaciones de los comerciantes alicantinos con el mercado español, de las que una parte importante era el tráfico con Cataluña, que podría verse en peligro de aplicarse un librecambismo más radical.

A diferencia de los comerciantes gaditanos que buscaron alianzas con otros sectores exportadores, dentro y fuera de Andalucía ${ }^{122}$, los mercaderes alicantinos, en su búsqueda de apoyos, apenas sobrepasaron el ámbito provincial ni probablemente

Montañés (2007), pp. 459-483. 
contaron con la burguesía valenciana, con la que, por otro lado, mantenían una fuerte rivalidad ${ }^{123}$. Incapaces de formar una asociación mercantil que reforzara su posición, como sucedió en Madrid o en Cádiz, fueron la Junta de Comercio, la Diputación o el Ayuntamiento, instituciones controladas por los comerciantes y hacendados, las que canalizaron esas demandas. Además, la coyuntura política también influyó en que no se consiguieran por completo los objetivos de apertura económica, pues la Regencia de Espartero duró poco y fue inestable políticamente; y los moderados no fueron demasiado propicios a la liberalización comercial.

\section{Fuentes}

Archivo Municipal de Alicante (AMA)

Borrador General de los establecimientos públicos de la ciudad de Alicante, 1842.

Armario 3. Legajo 32. Olim Diversorum.

Contribución de Guerra industrial, 1841. Armario 7. Libro 94.

Archivo Histórico Provincial de Alicante (AHPA)

Hacienda. Libro 1232. Subsidio de la Capital, 1844.

Hacienda. Libro 1394. Registro de aforos, 1847.

Hacienda. Libro 215.

Boletín Oficial de la Provincia (BOPA), 1852.

Diario de Sesiones de las Cortes (DSC), 1841.

El Mensajero, 1846, 1847.

La Gaceta, 1842, 1847.

\section{Bibliografía}

ALMENAR, Salvador (1976): “Agrarismo y librecambio en la crisis del Antiguo Régimen. El primer modelo de crecimiento económico de Álvaro Flórez Estrada", Información Comercial Española, 58, pp. 58-81.

-(1980): “El pensamiento económico de A. Flórez Estrada. Economía ricardiana y reformismo radical". Estudio preliminar a A. Flórez Estrada: Curso de economía politica, Madrid, IEF. 
-(2000): “Introducción. El desarrollo del pensamiento económico clásico en España", en FUENTES QUINTANA, Enrique (dir.), Economía y economistas españoles. Vol. 4. La economía clásica, Barcelona, Galaxia Gutenberg y Círculo de Lectores. ANTÓN RAMíREZ, Braulio (1988): Diccionario de bibliografía agronómica y de toda clase de escritos relacionados con la agricultura, seguido de un indice de autores y traductores con algunos apuntes biográficos, Madrid, MAPA.

ARGEMÍ Lluis y LLUCH, Ernest (1985): “La moderada y tímida penetración de la agronomía y la fisiocracia: un balance", en LLUCH, Ernest y ARGEMÍ, Lluís, Agronomía y fisiocracia en España, 1750-1820, Valencia, Alfons el Magnànim.

BAHAMONDE, Ángel y TORO, Julián (1976): “Los orígenes de la Sociedad Mercantil Matritense: estudio de un grupo de presión librecambista (1842-1846)", Anales del Instituto de Estudios Madrileños, tomo XII, pp. 239-243.

BERNAL Antonio M. y DE LA PEÑA, José F. (1974): “Formación de una gran propiedad agraria. Análisis de una contabilidad agrícola del siglo XIX", en NADAL, Jordi y TORTELLA, Gabriel (eds.), Agricultura, comercio colonial y crecimiento económico en la España contemporánea, Barcelona, Ariel, pp. 129-157.

CALATAYUD, Salvador (1999): “Difusión agronómica y protagonismo de las élites en los orígenes de la agricultura contemporánea: Valencia, 1840-1860", Historia Agraria, 17 pp. 99-127.

CALATAYUD, Salvador; MILLÁN, Jesús y ROMEO, Ma Cruz (1992): “Les transformacions de la societat agrària en el procés de desenvolupament capitalista: el regadiu valencià el segle XIX", Recerques, 25, pp. 125-138.

-(1996): “La noblesa propietària en la societat valenciana del segle XIX: el comte de Ripalda i la gestió del seu patrimoni", Recerques, 33, pp. 79-101.

-(2002a): "Poderes y legitimidad de la renta en el País Valenciano: las élites agrarias en el siglo XIX", Ayer, 46, pp. 233-262.

-(2002b): “El crèdit en el llindar de la societat burgesa: una aproximació al préstec agrari al regadiu valencià 1820-1840", en MIR, Conxita ; VICEDO, Enric (eds.), Control social $i$ quotidianitat. Terceres jornades sobre sistemes agraris, organització social i poder local als Països Catalans, Lleida, Institut d'Estudis Ilerdencs, pp. 375398.

CHASTAGNARET, Gérard (2000): L'Espagne, puissance minière dans l'Europe du XIX siècle, Madrid, Casa de Velázquez.

COMÍN, Francisco y VALLEJO, Rafael (2002): Alejandro Mon y Menéndez (1801-1882). Pensamiento y reforma de la Hacienda, Madrid, IEF.

“Contestación de la Junta de Agricultura de la provincia de Alicante al interrogatorio o encuesta agrícola de 1849", (1849) en VIDAL, Javier (1986), pp. 183-189.

COSTA, José (1977): El Marquesat de Dénia. Estudio Geográfico, Valencia, Universidad de Valencia, 1977, p. 196. 
CUEVAS, Joaquín (2000): “Fabricants, comerciants i banquers. La formació de l'empresariat industrial d'Alcoi el segle XIX", Recerques 41, pp. 77-108.

-(2001): "La financiación del desarrollo agrario valenciano, 1750-1914", Historia Agraria, 25, pp. 89-120.

DÍAZ, Pedro (1998a): Después de la revolución. Centralismo y burguesía en Alicante (1844-1854), I. C. “Juan Gil-Albert".

-(1998b): "Burgesia i ciutat. La política urbana a Alacant durant la Dècada Moderada (1844-1854)", Recerques, pp. 81-108.

-(2000): "Oligarquía y fiscalidad. Los primeros pasos de la contribución de inmuebles, cultivo y ganadería en la provincia de Alicante", Revista de Historia Económica, $\mathrm{n}^{\mathrm{o}} 2$, pp. 309-338.

-(2002): "Elecciones y práctica electoral en la provincia de Alicante bajo la ley de 1837", Comunicación presentada al Congreso internacional Orígenes del Liberalismo. Universidad, Política, Economía. (Universidad de Salamanca, 1 al 4 de octubre de 2002), Salamanca, publicada en CD-Rom, Departamento de Economía e Historia Económica, Universidad de Salamanca.

-(2003): “Crisis de subsistencia y protesta popular. Los motines de 1847", Historia Agraria, 30, pp. 31-62.

-(2004): "Rivalidades económicas entre Alicante y Valencia en el siglo XIX", en Josep Fontana. Història i projecte social. Reconeiximent a una trajectòria, Barcelona, Crítica, pp. 785-796.

-(2005): “Antecedentes históricos del trasvase del Júcar. La utopía hidráulica de la burguesía alicantina en el siglo XIX", Congreso Nacional gestión del agua en cuencas deficitarias. Orihuela, 5,6 y 7 de octubre de 2000, Centro de Investigación del Bajo Segura, Murcia, Alquibla, pp. 49-55.

-(2007): "Subsistence crisis and popular protest in Spain. The motines of 1847", en O'GRADA, Cormac; PAPING, Richard and VANHAUTE, Eric (eds.), When the potato failed. Causes and effects of the Last European Subsistence Crisis, 1845-1850, Turnhout, Brepols Publishers, pp. 267-292.

FERNÁNDEZ, Lourenzo (1998): “La política agraria del Estado español contemporáneo hasta 1936. Del propietario innovador al fomento de la innovación en la pequeña explotación", Historia Contemporánea, 17, pp. 237-286.

FERNÁNDEZ DE PINEDO, Emiliano (1999): “Notas al comercio de exportación español en la primera mitad del siglo XIX (1792-1849)" en Doctor Jordi Nadal: La industrialización y el desarrollo económico de España, Barcelona, Publicaciones de la Universidad de Barcelona, Vol.1, pp. 608-626.

FRADERA, Josep Ma (1987): Industria i mercat. Les bases comercials de la industria catalana moderna (1814-1845), Barcelona, Crítica.

FRAX, Esperanza (1981): Puertos y comercio de cabotaje en España. 1857-1934, Madrid, Servicio de Estudios del Banco de España. 
GALLEGO, Domingo (2005): “La formación de los precios del trigo en España (18201869): el mercado interior", Historia Agraria, 36, pp. 263-285.

GARRABOU, Ramón (1985a): "Sobre la modernidad de la agricultura "valenciana", en VVAA, La España de la Restauración. Política, economía, legislación y cultura, Madrid, pp. 331-344.

-(1985b): Un fals dilema. Modernitat o endrarreriment de l'agricultura valenciana 18501900, Valencia, Alfons el Magnànim.

GIMÉNEZ, Enrique (1981): Alicante en el siglo XVIII. Economía de una ciudad portuaria en el Antiguo Régimen, Valencia, Institución Alfonso el Magnánimo.

GÓMEZ, Gracia (2002): “Fabricantes y comerciantes. La ley de aranceles de 1841 y el debate proteccionismo-librecambio en la España liberal", Comunicación presentada al Congreso internacional Orígenes del Liberalismo. Universidad, Política, Economía (Universidad de Salamanca, 1 al 4 de octubre de 2002), Salamanca, publicada en CD-Rom, Departamento de Economía e Historia Económica, Universidad de Salamanca.

HERNÁNDEZ, Telesforo M. (1996): “Crédito y banca privada en el período de consolidación del capitalismo en el País Valenciano", en AZAGRA, Joaquín MATEU, Enric y VIDAL, Javier (eds.), De la sociedad tradicional a la economía moderna, Alicante, Instituto de Cultura "Juan Gil-Albert", pp. 196-215.

HOYO, Andrés (1993): Todo mudó de repente. El horizonte económico de la burguesía mercantil en Santander, 1820-1874, Santander, Universidad de Cantabria.

Informe presentado a las Juntas Generales de Agricultura de 1849 por su comisión novena, sobre las causas que contribuyen a que muchas de nuestras producciones agrícolas sean más caras que las de otras naciones, Madrid, 1849.

JOVELLANOS, Gaspar M. (1945): Informe sobre la ley agraria, Madrid, Espasa-Calpe.

JOVER, Nicasio C. (1863): Reseña histórica de la ciudad de Alicante, Alicante, Imprenta de la viuda de J.J. Carratalá.

LAFUENTE, Modesto (1922): Historia general de España. Desde los tiempos primitivos hasta la muerte de Fernando VII, continuada desde dicha época hasta la muerte de D. Alfonso XII, por D. Juan Valera en colaboración con D. Andrés Borrego, D. Antonio Pirala y D. José Coroleu y hasta la mayor edad de D. Alfonso XIII por D. Gabriel Maura y Gamazo, Barcelona, Montaner y Simón, 1922, Tomo 22.

LÓPEZ MORELL, Miguel A. (2005): La Casa Rothschild en España, Madrid, Marcial Pons.

LLOPIS, Enrique (2002): “Otras caras menos amables de la agricultura española contemporánea", Historia Agraria, 28, pp.179-198.

-(2003): “La agricultura española después de la guerra de la Independencia, 18151840: el boom roturador", en ROBLEDO, Ricardo; CASTELLS, Irene y ROMEO, $\mathrm{M}^{\mathrm{a}}$ Cruz (eds.), Orígenes del liberalismo. Universidad, política, economía, Salamanca, Universidad de Salamanca, pp. 320-324. 
LLUCH, Ernest (1988): “La gira triomfal, de Cobden per Espanya (1846)”, Recerques, XXI, pp. 71-90.

LLUCH, Ernest y ALMENAR, Salvador (2000): “Difusión e influencia de los economistas clásicos en España", en FUENTES, Enrique (dir.): Economía y economistas españoles. Vol. 4. La economía clásica, Barcelona, Galaxia Gutenberg y Círculo de Lectores.

MADOZ, Pascual (1995): Diccionario Geográfico-Histórico-Estadístico, Valencia, Librerías París-Valencia.

MATEU, Enric y CALATAYUD, Salvador (1996): “La evolución de la agricultura valenciana: algunos aspectos (1840-1939)", en AZAGRA, Joaquín; MATEU, Enric y VIDAL, Javier (eds.), De la sociedad tradicional a la economía moderna. Estudios de historia valenciana contemporánea, Alicante, Instituto de Cultura Juan GilAlbert pp. 101-124.

Memoria dirigida a la Regencia provisional del Reino por la Sociedad Económica de Amigos del País de la ciudad de Cádiz, sobre un tratado de comercio con la Inglaterra, reforma del sistema prohibitivo, y fomento de las fábricas nacionales (1841), Cádiz, Imprenta de Feros.

MILLÁN, Jesús (1981): “L'economia i la societat valencianes. Les transformacions d'un capitalisme perifèric", en História del País Valencià. Epoca Contemporània, Barcelona, Edicions 62.

-(1999): El poder de la tierra. La sociedad agraria del Bajo Segura en la época del liberalismo 1830-1890, Alicante, Instituto de Cultura "Juan Gil-Albert".

-(2000): “Liberalismo y reforma agraria en los orígenes de la España Contemporánea", Brocar, 24, pp. 181-211.

MONTAÑÉS, Enrique (2007): “Vinos y cuestión algodonera. Los exportadores ante la reforma agraria, 1839-1843", Historia Agraria, pp. 459-483.

MORILLA, José; OLMSTEAD, Alan y RHODE, Paul (2000): “International competition and the development of the dried-fruit industry, 1880-1930", en PAMUK, Sevked and WILLIAMSON, Jeffrey G., The Mediterranean response to Globalization before 1950, London, Routledge, pp. 199-232.

NADAL, Joaquim (1978): Comercio exterior con Gran Bretaña (1777-1914), Madrid, IEF. OTAZU, Alfonso (1987): Los Rothschild y sus socios en España (1820-1850), Madrid, O. Hs. Ediciones.

PERDICES, Luis (1978): “Traducciones al español de libros de economía política (1800-1880), Moneda y Crédito, 147, pp. 71-103.

-(2000): "La riqueza de las naciones y los economistas españoles”, en FUENTES, Enrique (dir.), Economía y economistas españoles, 4. La economía clásica, Barcelona, Galaxia Gutenberg y Círculo de Lectores, pp. 269-303.

PIQUERAS, Juan (1983): La vid y el vino en el País Valenciano, Valencia, Institución Alfonso el Magnánimo. 
-(1985): La agricultura valenciana de exportación y su formación histórica, Madrid, Instituto de Estudios Agrarios, Pesqueros y Alimentarios.

-(1986): Guía de los vinos valencianos, Valencia.

PLAZA, Juan (1992): “Población y riqueza imponible en España a mediados del siglo XIX", GARCÍA DELGADO, José Luis (comp.), Economía española, Cultura y Sociedad. Homenaje a Juan Velarde Fuertes, Madrid, Eudema, pp. 273-297.

PRADOS, Leandro (1984): “La evolución del comercio exterior, 1790-1929", Papeles de Economía Española, 20, pp. 137-138.

-(1988): De Imperio a nación. Crecimiento y atraso económico en España (1780-1930). Madrid, Alianza.

-(1988): “Comercio exterior y cambio económico en España (1792-1849)", en FONTANA, Josep (ed.), La economía española al final del Antiguo Régimen III. Comercio y colonias, Madrid, Alianza Universidad.

PRO, Juan (1987): "Información fiscal agraria, redes clientelares y progresismo: la estadística de la riqueza de 1841", Revista internacional de sociología, Vol. 45 (1), pp. 199-216.

RAVIX, Joel (1991): “Le libre-échange et le proteccionisme en France”, en BRETON, Yves y LUTFALLA, Michel (dirs.), L'economie politique en France au XIX siècle, París, Economica.

Representación elevada al serenísimo señor regente del reino por la Diputación Provincial y Junta de Comercio de Alicante en favor de la introducción de manufacturas extranjeras en España (1842), en VIDAL, Javier (1986), pp. 45-52.

ROCA DE TOGORES, Joaquín (1986 [1849]): "Memoria sobre el estado de la agricultura en la provincia de Alicante. 1849", en VIDAL, Javier, Materiales para la historia económica de Alicante, Alicante, I. C. "Juan Gil-Albert", pp. 53-181.

RODRÍGUEZ, Manuel (1985): “Espartero y las relaciones comerciales hispano-británicas, 1840-1843. Hispania, pp. 323-361.

ROMEO, Ma Cruz (1992): Entre el orden y la revolución. La formación de la burguesía liberal en la crisis de la monarquía absoluta (1814-1833), Alicante I.C. "Juan Gil-Albert".

ROSÉS, Joan R. (2001): “La competitividad internacional de la industria algodonera española (1830-1860), Revista de Historia Económica, número extraordinario, pp. 85-109.

RUIZ, Pedro (1985): “Desarrollo y crisis de la agricultura en el País Valenciano a finales del Antiguo Régimen" en GARRABOU, Ramon y GARCÍA SANZ, Ángel (eds.), Historia agraria de la España contemporánea, Vol. 1, Barcelona, Crítica.

SALORT, Salvador (1998): La Hacienda Local en la España Contemporánea. La Hacienda Municipal de Alacant (1800-1923), Alacant, Institut de Cultura "Juan Gil Albert". SÁEZ, Miguel A. (2004): "Herraduras, clavos y arados. Siderurgia y demanda agraria en la España de la segunda mitad del siglo XIX", Revista de Historia Industrial, 26, pp. 183-207. 
SÁNCHEZ LEÓN, Pablo (1999): Libertad económica versus pluralismo político: la movilización a favor del libre comercio en Inglaterra y España, Documento de Trabajo 0399 del Seminario de Historia Contemporánea, Instituto Universitario Ortega y Gasset.

SÁNCHEZ, Alex (2000): “Crisis económica y respuesta empresarial. Los inicios del sistema fabril en la industria algodonera catalana, 1797-1839", Revista de Historia Económica, 3, pp. 485-523.

SÁNCHEZ RECIO, Glicerio (1986): La desamortización de Mendizábal en la provincia de Alicante. El clero regular: 1836-1850, Alicante, Instituto de Estudios "Juan GilAlbert".

SCHWARTZ, Pedro (1999): "Estudio preliminar" a De la libertad de comercio por José Joaquín de Mora, Madrid, IEF.

TORRÓ, Lluís (2001): “Despatxar els draps. Una aproximació als mercats y les formes de comercialització de la draperia alcoiana al set-cents", Recerques, 42, pp. 147-166.

VALLEJO, Rafael (2001): Reforma tributaria y fiscalidad sobre la agricultura en la España liberal, 1845-1900, Zaragoza, Prensas Universitarias de Zaragoza.

VELASCO, Rogelio (1990): Pensamiento económico en Andalucía (1800-1850). Economía política, librecambismo y proteccionismo, Málaga, Librería Ágora.

VIDAL, Javier (1986): Materiales para la historia económica de Alicante, Alicante, I. C. "Juan Gil-Albert".

VILAR, Juan B. y EGEA, Pedro (1990): La minería murciana contemporánea (1840-1930), Murcia, Universidad de Murcia. 